\title{
A study of acid phosphatase locus 1 in women with high fat content and normal body mass index
}

\author{
Antonino De Lorenzo ${ }^{a}$, Laura Di Renzo ${ }^{\mathrm{a}}$, Alberto Puja ${ }^{\mathrm{b}}$, Patrizia Saccucci ${ }^{\mathrm{c}}$, \\ Fulvia Gloria-Bottini ${ }^{\mathrm{d}, *}$, Egidio Bottini ${ }^{\mathrm{d}}$ \\ ${ }^{a}$ Department of Neurosciences, Human Nutrition Unit, University of Rome Tor Vergata, 00133 Rome, Italy \\ ${ }^{\mathrm{b}}$ Dentistry Department, University of Rome Tor Vergata, 00133 Rome, Italy \\ ${ }^{\mathrm{c}}$ Department of Internal Medicine, University of Rome Tor Vergata, 00133 Rome, Italy \\ ${ }^{\mathrm{d}}$ Department of Biopathology and Imaging Diagnostics, University of Rome Tor Vergata, 00133 Rome, Italy
}

Received 7 February 2008; accepted 13 October 2008

\begin{abstract}
De Lorenzo and coworkers have recently described a class of women with normal body mass index (BMI) and high fat content (normal weight obese syndrome [NWO]). This observation prompted us to study the possible role of acid phosphatase locus 1 (ACP ${ }_{1}$ in the differentiation of this special class of obese subjects. Acid phosphatase locus 1 is a polymorphic gene associated with severe obesity and with total cholesterol and triglycerides levels. The enzyme is composed by 2 isoforms - F and S-that have different biochemical properties and probably different functions. The sample study was composed of 130 white women from the population of Rome. Total fat mass and percentage of fat mass were measured by dual-energy x-ray absorptiometry. Thirty-six women had a BMI less than 25 and percentage of fat mass greater than 30 (high fat, normal BMI [HFHB]), and 94 women showed a BMI greater than 25 and a percentage of fat mass greater than 30 (high fat, high BMI [HFHB]). In the whole sample, the proportion of low-activity $\mathrm{ACP}_{1}$ genotypes $\left(* \mathrm{~A} / *^{*} \mathrm{~A}\right.$ and $\left.* \mathrm{~B} / *^{*} \mathrm{~A}\right)$ was higher than in controls. However, whereas HFNB showed a very high frequency of $\mathrm{ACP}_{1} * \mathrm{~A} / * \mathrm{~A}$ genotype, high-fat, high-BMI women showed an increase of $* \mathrm{~B} / * \mathrm{~A}$ genotype. These 2 genotypes differ in the concentration of $\mathrm{F}$ isoform and the $\mathrm{F} / \mathrm{S}$ ratio, which are lower in $\mathrm{ACP}{ }_{1}^{*} \mathrm{~A} / * \mathrm{~A}$ genotype than in $\mathrm{ACP}_{1}^{*} \mathrm{~B} / * \mathrm{~A}$ genotype. The genetic differentiation of the class of women with normal $\mathrm{BMI}$ and high fat content from the class showing a concordant level of the 2 parameters supports the hypothesis that HFNB class represents a special cluster of obese subjects not revealed by $\mathrm{BMI}$ evaluation. Because $\mathrm{ACP}_{1}$ is present in adipocytes, the present observation suggests that $\mathrm{F}$ isoform may have a specific role in the regulation of quantity of adipose tissue.
\end{abstract}

(C) 2009 Elsevier Inc. All rights reserved.

\section{Introduction}

The term obesity indicates an excess of body fat associated to health problems. Although body mass index (BMI) is still considered the cornerstone for classification of obesity disorders, it can provide misleading information about actual body fat content. Correlation analysis has shown that only $58 \%$ of the variance of fat content in adolescents and $66 \%$ of the variance of fat content in adults can be predicted by BMI $[1,2]$. This indicates that, besides factors that influence in a concordant manner both parameters, there are many other factors that influence fat composition but not BMI and vice versa.

\footnotetext{
* Corresponding author. Tel.: +39 6 72596030; fax: +39672596028.

E-mail address: gloria@med.uniroma2.it (F. Gloria-Bottini).
}

The relationship between $\mathrm{BMI}$ and fat content is influenced by age and sex. Moreover, the correlation is different among ethnic groups [3]. Besides environmental, cultural, and alimentary factors, it is likely that genetic factors have an important role in ethnic differences and in the degree of correlation between BMI and fat composition.

\subsection{Acid phosphatase locus 1 genetic polymorphism, BMI, and blood lipid}

Acid phosphatase locus $1\left(\mathrm{ACP}_{1}\right)$ is a polymorphic gene located on chromosome 2 showing 3 common codominant alleles: $\mathrm{ACP}_{1}^{*} \mathrm{~A}, \mathrm{ACP}_{1}^{*} \mathrm{~B}$, and $\mathrm{ACP}_{1}^{*} \mathrm{C}$. The corresponding 6 genotypes are associated with different enzymatic activity: Spencer et al [4] found the following activities (micromoles of $p$-nitrophenol produced in 30 minutes per gram of hemoglobin at $\left.37^{\circ} \mathrm{C}\right): \mathrm{ACP}_{1}^{*} \mathrm{~A} / * \mathrm{~A}, 122.4 ; \mathrm{ACP}_{1}^{*} \mathrm{~A} /{ }^{*} \mathrm{~B}, 153.9 ; \mathrm{ACP}_{1}^{*} \mathrm{~B} /{ }^{*} \mathrm{~B}$, 
188.3; $\mathrm{ACP}_{1}^{*} \mathrm{~A} /{ }^{*} \mathrm{C}, 183.8$; and $\mathrm{ACP}_{1}^{*} \mathrm{~B} /{ }^{*} \mathrm{C}, 212.3$. The ${ }^{*} \mathrm{C} /{ }^{*} \mathrm{C}$ genotype is very rare, and its activity is about 240.0 .

At present, the term $A C P_{1}$ is used to indicate the gene, whereas the protein product is called low-molecular weight protein tyrosine phosphatase (LMPTP).

Two functions have been suggested for LMPTP: flavin mononucleotide phosphatase and protein tyrosine phosphatase. By catalyzing the conversion of flavin mononucleotide to riboflavin, LMPTP may have a role in regulating the cellular concentration of flavin adenine dinucleotide, flavoenzyme activity, and energy metabolism. As protein tyrosine phosphatase, the enzyme may have an important role in modulation of glycolytic rate through the control of insulin receptor activities and of band 3 protein phosphorylation [5].

Low-molecular weight protein tyrosine phosphatase is involved in vitro in the negative modulation of insulin signal transduction [6] and is able to in vitro dephosphorylate the adipocyte lipid binding protein (ALBP) [7]. ALBP belongs to a family of binding lipid proteins present in various isoforms in many human tissues. In adipose tissue, ALBP is phosphorylated on Tyr19 after insulin stimulation; and this phenomenon seems to impair its fatty acid binding ability [8]. In the adipose tissue, the double activity of LMPTP (on insulin receptor insulin transduction and ALBP phosphorylation) could partly compensate each other.

Insulin signal transduction is well known to be modulated by other cytosolic insulin tyrosine phosphatases that act with higher affinity than $\mathrm{ACP}_{1}[9]$. Two transmembrane phosphatases in adipocytes that are responsible for the phosphorylating ALBP with high affinity have been isolated [10]. The effect of LMPTP may become evident in the regulation of metabolic signaling only in pathologic situation when other control systems usually acting with higher affinity are failing.

Low-molecular weight protein tyrosine phosphatase shows 2 isoforms - F and $\mathrm{S}$ - that have different biochemical properties. Stefani et al [11] have studied the dephosphorylation of tyrosine phosphorylated synthetic peptides by rat liver phosphotyrosine protein phosphatase isoenzymes and have found differences in main kinetic parameters of $\mathrm{F}$ and $\mathrm{S}$ isoenzymes for insulin receptor and B3P phosphorylated peptides (Table 1). Acid phosphatase locus 1 genotypes show different concentrations of the 2 isoforms (Table 2).

Table 1

Kinetic parameters of $\mathrm{F}$ and $\mathrm{S} \mathrm{ACP}{ }_{1}$ isoforms for insulin receptor and $\mathrm{B} 3 \mathrm{P}$ synthetic phosphotyrosine-containing peptides (modified from Stefani et al [11])

\begin{tabular}{lrr}
\hline & $\mathrm{F}$ & $\mathrm{S}$ \\
\hline$K m$ & & \\
Insulin receptor & 0.4 & 0.6 \\
B3P & 1.4 & 0.4 \\
& & \\
Imax & & 4.6 \\
Insulin receptor & 3.1 & 10.5 \\
B3P & 68.0 & \\
\hline
\end{tabular}

Table 2

$\mathrm{F}$ and $\mathrm{S}$ isozyme concentrations in relation to the $\mathrm{ACP}_{1}$ genotype

\begin{tabular}{|c|c|c|c|c|c|}
\hline \multicolumn{2}{|c|}{$\begin{array}{l}\text { Total quantity of } \\
\mathrm{F}(\mu \mathrm{g} / \mathrm{mL} \mathrm{RBC})\end{array}$} & \multicolumn{2}{|c|}{$\begin{array}{l}\text { Total quantity of } \\
\mathrm{S}(\mu \mathrm{g} / \mathrm{mL} \mathrm{RBC})\end{array}$} & \multicolumn{2}{|c|}{$\mathrm{F} / \mathrm{S}$ ratio } \\
\hline$* \mathrm{~B} /{ }^{*} \mathrm{~B}$ & 16.4 & $* \mathrm{C} / * \mathrm{C}$ & 20.6 & $* \mathrm{~B} /{ }^{*} \mathrm{~B}$ & 4.2 \\
\hline$* \mathrm{~B} / * \mathrm{~A}$ & 12.0 & $* \mathrm{C} / * \mathrm{~A}$ & 12.7 & $* \mathrm{~B} / * \mathrm{~A}$ & 3.6 \\
\hline$* \mathrm{C} / *^{*} \mathrm{~B}$ & 11.3 & $* \mathrm{C} / * \mathrm{~B}$ & 12.1 & $* \mathrm{~A} / * \mathrm{~A}$ & 2.4 \\
\hline$* \mathrm{~A} / * \mathrm{~A}$ & 7.9 & $* \mathrm{~B} / *^{*} \mathrm{~B}$ & 3.9 & $* \mathrm{C} /{ }^{*} \mathrm{~B}$ & 0.9 \\
\hline$* \mathrm{C} / * \mathrm{~A}$ & 7.5 & $* \mathrm{~B} / * \mathrm{~A}$ & 3.4 & $* \mathrm{C} / * \mathrm{~A}$ & 0.6 \\
\hline$* \mathrm{C} / *^{*}$ & 5.7 & $* \mathrm{~A} / * \mathrm{~A}$ & 3.3 & ${ }^{*} \mathrm{C} / * \mathrm{C}$ & 0.3 \\
\hline
\end{tabular}

The quantities of enzyme are given per milliliter of packed red cells [12]. $\mathrm{RBC}$ indicates red blood cells.

Acid phosphatase locus 1 dephosphorylates a tyrosine residue of erythrocyte membrane protein 3 (B3P). Band 3 is the erythrocyte anion transporter. Tyrosine phosphorylation of the anion transporter prevents binding of several glycolytic enzymes and results in elevated glycolytic rates [13]. Thus, a mechanism can be constructed whereby the genotypic differences in $\mathrm{ACP}_{1}$ activity regulate erythrocyte metabolism via an interface with glycolysis.

Acid phosphatase locus 1 has been found to be associated with severe obesity [14]. The $\mathrm{ACP}_{1}$ genotypes $* \mathrm{~A} / * \mathrm{~A}$ and $* \mathrm{~B} /{ }^{*} \mathrm{~A}$ that have the lowest levels of total LMPTP activity are significantly higher in severely obese nondiabetic individual. The $\mathrm{ACP}_{1}^{*} \mathrm{~A}$ allele has been found to be negatively associated with the levels of total cholesterol $(P=.002)$ and triglycerides $(P<.001)$ in obese white subjects in the United States [15].

The pattern of association between the $\mathrm{ACP}_{1}$ genetic polymorphism and clinical variability of obesity suggests a multipoint action of this ubiquitous phosphatase. Its expression in adipocytes suggests that $\mathrm{ACP}_{1}$ may affect the behavior of these cells in a genotype-dependent manner. A function as flavin mononucleotide phosphatase to regulate the overall rate of respiration and metabolism could explain at least some of these observations. Dephosphorylation of insulin receptor is another possibility. Recent experiments using specific antisense oligonucleotide to reduce LMPTP expression both in vivo and in vitro indicate that the enzyme is a key negative regulator of insulin action [16].

De Lorenzo et al [17] have recently described a class of women with normal BMI and high fat content (NWO [18]). This class of women is similar to the class of overweightobese women not only for lean body mass distribution but also for cardiovascular risk indexes values [17].

In the present note, we have searched for possible effect of $\mathrm{ACP}_{1}$ genotypes in the differentiation between the 2 classes of women.

\section{Subjects and methods}

The sample study was composed of 130 white women from the population of Rome. Thirty-six women had a BMI less than 25 and percentage of fat mass greater than 30 , and 94 women showed a BMI greater than 25 and percentage of 
Table 3

Distribution of $\mathrm{ACP}_{1}$ genotypes in $\mathrm{HFNB}, \mathrm{HFHB}$, and healthy adults from the white population of Rome

\begin{tabular}{lccc}
\hline $\mathrm{ACP}_{1}$ genotype & HFNB & HFHB & Healthy adults \\
\hline$* \mathrm{~A} / * \mathrm{~A}$ & $22.5 \%$ & $8.5 \%$ & $8.6 \%$ \\
$* \mathrm{~B} / *^{\mathrm{B}}$ & $41.7 \%$ & $37.2 \%$ & $43.9 \%$ \\
$* \mathrm{~B} /{ }^{*} \mathrm{~A}$ & $22.2 \%$ & $45.7 \%$ & $31.6 \%$ \\
$* \mathrm{C} / * \mathrm{~A}$ & $5.6 \%$ & $4.3 \%$ & $3.4 \%$ \\
$* \mathrm{C} / \mathrm{B}^{\mathrm{B}}$ & $8.3 \%$ & $4.3 \%$ & $12.2 \%$ \\
Total $\mathrm{n}$ & 36 & 94 & 416 \\
\hline
\end{tabular}

fat mass greater than 30. Circumference at waist was $71.84 \pm$ 4.80 for the first group and $90.17 \pm 13.57$ for the second group $(P<.001)$. Circumference at hip was $96.05 \pm 8.07$ and $108.70 \pm 23.06$ for the first and the second group, respectively $(P<.01)$.

None of the individuals had either impaired glucose tolerance/diabetes or clinical history of cardiovascular risk. No individuals were taking any medication. Participants were randomly selected among all the participants to the studies on the basis of body composition and energy metabolism at the Unit of Human Nutrition of Tor Vergata University, Rome, Italy.

Informed consent was obtained from all the participants before the beginning of the study, according to Medical Ethics Committee Guidelines of the University.

Body mass index was calculated using the following formula: BMI = body weight (in kilograms)/height (in square meters). Total fat mass and percentage of fat mass were measured by dual-energy x-ray absorptiometry (Model DPX, software revision 3.6; Lunar, Madison, WI). The $\mathrm{ACP}_{1}$ genotype was determined by DNA analysis as previously described [19].

A sample of 416 healthy blood donors from the same white population has been also reported to compare the $\mathrm{ACP}_{1}$ distribution of the sample study with that of the general population.

\section{Results}

Tables 3 and 4 show the distribution of $\mathrm{ACP}_{1}$ genotypes in high-fat, normal-BMI women (HFNB); in high-fat, overweight women (HFHB); and in a control sample (blood donors) from the same white population. In the whole sample of women (including HFNB and HFHB), the

Table 4

Statistical analysis of data reported in Table 3

\begin{tabular}{lrrr}
\hline$\chi^{2}$ Test of independence comparison & \multicolumn{1}{c}{$\chi^{2}$} & $d f$ & $P$ \\
\hline A vs B vs C (all ACP 1 genotypes) & 18.673 & 8 & .017 \\
A vs B (all ACP 1 genotypes) & 8.680 & 4 & .070 \\
A vs B vs C $(* \mathrm{~A} / * \mathrm{~A}$ vs *B/*A vs other ACP 1 types) & 15.089 & 4 & .004 \\
A vs B $\left(* \mathrm{~A} / * \mathrm{~A}\right.$ vs $* \mathrm{~B} / * \mathrm{~A}$ vs other $\mathrm{ACP}_{1}$ types $)$ & 8.164 & 2 & .017 \\
$\mathrm{~A}$ vs B $(* \mathrm{~A} / * \mathrm{~A}$ vs $* \mathrm{~B} / * \mathrm{~A})$ & 7.892 & 1 & .005 \\
\hline
\end{tabular}

A indicates HFNB; B, HFHB; $C$, healthy adults.
Table 5

Odds ratio analysis

\begin{tabular}{lcl}
\hline & OR & $95 \%$ Confidence interval \\
\hline$A C P_{1}^{*} A /^{*} A$ vs other $A C P_{1}$ types & \\
A vs controls & 3.01 & $1.17-7.58$ \\
$\mathrm{~B}$ vs controls & 0.98 & $0.40-2.29$ \\
$\mathrm{~A}$ vs B & 3.07 & $0.94-10.10$ \\
& & \\
$A C P_{1}^{*} B{ }^{*} A$ vs other $A C P_{1}$ types & \\
$\mathrm{A}$ vs controls & 0.61 & $0.25-1.45$ \\
$\mathrm{~B}$ vs controls & 1.81 & $1.12-2.93$ \\
$\mathrm{~A}$ vs B & 0.33 & $0.13-0.88$ \\
\hline
\end{tabular}

OR indicates odds ratio; A, HFNB; B, HFHB.

proportions of $\mathrm{ACP}_{1}^{*} \mathrm{~A} / * \mathrm{~A}$ and $* \mathrm{~B} / * \mathrm{~A}$ genotypes are higher than those in controls $(P<.025)$, confirming previous observations on obese subjects [13]. However, there are significant differences between HFNB and HFHB concerning the proportion of $\mathrm{ACP}_{1}^{*} \mathrm{~A} / * \mathrm{~A}$ and $* \mathrm{~B} / * \mathrm{~A}$ genotypes: in $\mathrm{HFNB}$, there is a strong increase of $\mathrm{ACP}_{1}^{*} \mathrm{~A} / * \mathrm{~A}$ genotype but a decrease of $\mathrm{ACP}_{1}^{*} \mathrm{~B} / * \mathrm{~A}$ genotype as compared with controls, whereas in $\mathrm{HFHB}$, the $\mathrm{ACP}_{1}^{*} \mathrm{~A} /{ }^{*} \mathrm{~A}$ genotype is not increased but the $\mathrm{ACP}_{1}^{*} \mathrm{~B} / * \mathrm{~A}$ genotype is strongly increased as compared with controls. The ratio of $* \mathrm{~A} / * \mathrm{~A}$ to $* \mathrm{~B} / * \mathrm{~A}$ is 1.01 in HFNB and 0.19 in HFHB $(P=.005)$.

Table 5 shows an odds ratio analysis. The risk for HFNB vs controls is 3.01 for $\mathrm{ACP}_{1}^{*} \mathrm{~A} /{ }^{*} \mathrm{~A}$ genotype vs other genotypes; the risk for HFHB vs controls is 1.81 for $\mathrm{ACP}_{1}^{*} \mathrm{~B} / *$ A genotype vs other genotypes.

Table 6 shows $\mathrm{F}$ and $\mathrm{S}$ isoforms concentrations and $\mathrm{F} / \mathrm{S}$ ratio of HFNB, HFHB, and controls in subjects carrying the ${ }^{*} \mathrm{~A} /{ }^{*} \mathrm{~A}$ and $* \mathrm{~B} /{ }^{*} \mathrm{~A}$ genotypes. All parameters are significantly different between HFNB and HFHB and between HFNB and controls, resulting in a statistically significant lower $\mathrm{F} / \mathrm{S}$ ratio in HFNB as compared with HFHB and controls.

\section{Discussion}

Body mass index does not discriminate between muscle and adipose tissues and does not directly assess regional adiposity. In general, measures of fat distribution are more

Table 6

The $\mathrm{ACP}_{1}$ isoforms in HFNB, HFHB, and controls carrying the $\mathrm{ACP}_{1}^{*} \mathrm{~A} /{ }^{*} \mathrm{~A}$ and $* \mathrm{~B} / *$ A genotypes

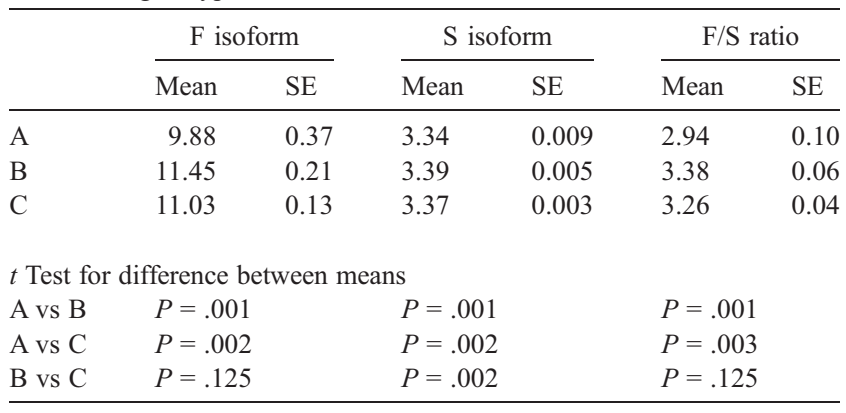

A indicates HFNB; B, HFHB; C, healthy adults. 
correlated with cardiovascular disease risk factors and diabetes than BMI.

The present data confirm the overall positive association of obesity with low-activity $\mathrm{ACP}_{1}^{*} \mathrm{~A} / * \mathrm{~A}$ and $* \mathrm{~B} / * \mathrm{~A}$ genotypes but show significant differences between $\mathrm{ACP}_{1}^{*} \mathrm{~A} / * \mathrm{~A}$ genotype and $\mathrm{ACP}_{1}^{*} \mathrm{~B} /{ }^{*} \mathrm{~A}$ genotype concerning the pattern of association with obesity parameters. The *A/*A genotype shows a tendency to an increase to adipose tissue even in the presence of normal BMI, and this may have importance for the risk of cardiovascular disease and diabetes. Although suggestive, the observation needs to be confirmed in other clinical setting and in other populations before drawing definitive conclusions.

Both $\mathrm{ACP}_{1} * \mathrm{~A} / * \mathrm{~A}$ and $* \mathrm{~B} / * \mathrm{~A}$ genotypes show a low LMPTP total activity but differ in $\mathrm{F}$ isoform concentration and in $\mathrm{F} / \mathrm{S}$ ratio; both parameters are sensibly lower in $\mathrm{ACP}_{1}^{*} \mathrm{~A} / * \mathrm{~A}$ genotype than in $\mathrm{ACP} 1 * \mathrm{~B} /{ }^{*} \mathrm{~A}$ genotype. In this context, it may be interesting to note (Table 3 ) that the frequency of $\mathrm{ACP}_{1}^{*} \mathrm{C} / * \mathrm{~A}$ and ${ }^{*} \mathrm{C} /{ }^{*} \mathrm{~B}$ genotypes that share a low $\mathrm{F}$ and a low $\mathrm{F} / \mathrm{S}$ ratio is higher in HFNB than in HFHB; but these differences are not statistically significant.

As shown in Table 1, Km of F isoform is lower for insulin receptor than for $\mathrm{B} 3 \mathrm{P}$, whereas $\mathrm{Km}$ of $\mathrm{S}$ isoform is higher for insulin receptor than for B3P. On the other hand, Vmax of F isoform is much higher for B3P than for insulin receptor, whereas Vmax of $\mathrm{S}$ isoform shows similar but less marked difference. This could be a biochemical basis for the differences observed between $\mathrm{ACP}_{1}$ genotypes concerning the glycemic level that have been observed in normal and diabetic subjects [20,21].

As far as we know, similar experiments have not yet been carried out on ALBP: differences in kinetic parameters of $\mathrm{F}$ and $\mathrm{S}$ for insulin receptor and ALBP could be important for fat disposal, thus explaining the pattern of association presently reported. Further investigations in this area are warranted and could be rewarding.

\section{References}

[1] Prentice AM, Jebb SA. Beyond body mass index. Obes Rev 2001;2: 141-7.

[2] Hannan WJ, Wrate RM, Cowen SJ, Freeman CP. Body mass index as an estimate of body fat. Int J Eat Disord 1995;18:91-7.

[3] Deurenberg P, Yap M, Van Staveren WA. Body mass index and percent body fat: a meta analysis among different ethnic groups. Int J Obes Relat Metab Disord 1998;22:1164-71.

[4] Spencer N, Hopkinson DA, Harris H. Quantitative differences and gene dosage in the human red cell acid phosphatase polymorphism. Nature 1964;201:299-300.
[5] Bottini N, Bottini E, Gloria-Bottini F, Mustelin T. Low-molecularweight protein tyrosine phosphatase and human disease: in search of biochemical mechanisms. Arch Immunol Ther Exp 2002;50:95-104.

[6] Chiarugi P, Cirri P, Marra F, Raugei G, Camici G, Manao G, et al. LMW-PTP is a negative regulator of insulin-mediated mitotic and metabolic signalling. Biochem Biophys Res Commun 1997;238: 676-82.

[7] Shekels LL, Smith AJ, Van Etten RL, Bernlohr DA. Identification of the adipocyte acid phosphatase as a PAO-sensitive tyrosyl phosphatase. Protein Sci 1992;1:710-21.

[8] Buelt MK, Xu Z, Banaszak LJ, Bernlohr DA. Structural and functional characterization of the phosphorylated adipocyte lipid-binding protein (pp15). Biochemistry 1992;31:3493-9.

[9] Elchebly M, Cheng A, Tremblay ML. Modulation of insulin signaling by protein tyrosine phosphatases. J Mol Med 2000;78:473-82.

[10] Liao K, Hoffman RD, Lane MD. Phosphotyrosyl turnover in insulin signaling. Characterization of two membrane-bound pp15 protein tyrosine phosphatases from 3T3-L1 adipocytes. J Biol Chem 1991; 266:6544-53.

[11] Stefani M, Caselli A, Bucciantini M, Pazzagli L, Dolfi F, Camici G, et al. Dephosphorylation of tyrosine phosphorylated synthetic peptides by rat liver phosphotyrosine protein phosphatase isoenzymes. FEBS Lett 1993;326:131-4.

[12] Dissing J, Johnsen AH. Human red cell acid phosphatase (ACP1): the primary structure of the two pairs of isozymes encoded by the ACP1*A and ACP1*C alleles. Biochim Biophys Acta 1992;1121:261-8.

[13] Harrison ML, Rathinavelu P, Arese P, Geahlen RL, Low PS. Role of band 3 tyrosine phosphorylation in the regulation of erythrocyte glycolysis. J Biol Chem 1991;266:4106-11.

[14] Paggi A, Borgiani P, Gloria-Bottini F, Russo S, Saponara I, Banci M, et al. Further studies on acid phosphatase in obese subjects. Dis Markers 1991;9:1-7.

[15] Bottini N, MacMurray J, Peters W, Rostamkhani M, Comings DE. Association of the acid phosphatase (ACP1) gene with triglyceride levels in obese women. Mol Genet Metab 2002;77:226-9.

[16] Pandey SK, Yu XX, Watts LM, Michael MD, Sloop KW, Rivard AR, et al. Reduction of low molecular weight protein-tyrosine phosphatase expression improves hyperglycemia and insulin sensitivity in obese mice. J Biol Chem 2007;282:14291-9.

[17] De Lorenzo A, Martinoli R, Vaia F, Di Renzo L. Normal weight obese (NWO) women: an evaluation of a candidate new syndrome. Nutr Metab Cardiovasc Dis 2006;16:513-23.

[18] De Lorenzo A, Del Gobbo V, Premrov MG, Bigioni M, Galvano F, Di Renzo L. Normal weight obese syndrome: early inflammation? Am J Clin Nutr 2007;85:4045.

[19] Bottini N, Meloni GF, Borgiani P, Giorgini A, Buzzetti R, Pozzilli P, et al. Genotypes of cytosolic low-molecular-weight protein-tyrosinephosphatase correlate with age at onset of type 1 diabetes in a sexspecific manner. Metabolism 2002;51:419-22.

[20] Iannaccone U, Bergamaschi A, Magrini A, Marino G, Bottini N, Lucarelli P, et al. Serum glucose concentration and ACP1 genotype in healthy adult subjects. Metabolism 2005;54:891-4.

[21] Gloria-Bottini F, Gerlini G, Lucarini N, Borgiani P, Amante A, La Torre $\mathrm{M}$, et al. Phosphotyrosine protein phosphatases and diabetic pregnancy: an association between low molecular weight acid phosphatase and degree of glycemic control. Experientia 1996; 52:340-3. 